\title{
A study on economic empowerment of women through self- help groups (IWMP-Morbi Taluka)
}

\author{
Hemangi D. Mehta and Jyoti S. Han
}

Received: 29.08.2020; Revised: 05.11.2020; Accepted: 25.11.2020

See end of the paper for authors' affiliations Hemangi D. Mehta Krushi Vigyan Kendra (JAU), Morbi (Gujarat) India Email : hemangidmehta@gmail. com; drhemangimehta@jau.in
ABSTRACT : This paper focuses on the level of women empowerment in rural areas. Women are critical to a thriving rural economy, especially in developing countries such as India. Rural women today have been suffering a lot due to the feeling of helplessness and lack of decisionmaking capabilities in financial matters. Self-help groups (SHGs) are the most recent development for them which could enable them to come forward and make them self dependent and self employed. The main objective of this study is SHGs Contribution of empowerment level in rural areas women. Self -help groups have been playing considerable role in communication level of members, change in family violence, frequency of interaction with outsiders, change in the saving pattern of SHG members, achieving social harmony and sustainability-financial value.

KEY WORDS: Women empowerment, Roll of self help group, Self dependent, Self - employed

- HOW TO CITE THIS PAPER : Mehta, Hemangi D. and Han, Jyoti S. (2020). A study on economic empowerment of women through self- help groups (IWMP-Morbi Taluka). Asian J. Home Sci., 15 (2) : 342-344, DOI: 10.15740/HAS/AJHS/15.2/342-344. Copyright@ 2020: Hind Agri-Horticultural Society. 